\begin{tabular}{l}
\hline Jurnal Scripta Teologi dan Pelayanan Kontekstual \\
ISSN \\
ISSN \\
Http://ejournal.stte.ac.id \\
Vol.4, No.2, pp. 152-163, 2019
\end{tabular}

\title{
Manajemen Mutu Dan Pendidikan Mutu Melalui Standar Penjaminan Mutu (SPMI) Di STT Ebenhaezer
}

Fanny Y. M. Kaseke

'STT Ebenhaezer Tanjung Enim, Yapimarkus73@gmail.com

\begin{tabular}{l}
\hline INFO ARTIKEL \\
\hline Sejarah Artikel: \\
Diterima : 08 Nov 2019 \\
Direvisi : 15 Nov 2019 \\
Disetujui: 22 Nov 2019 \\
Dipublikasi: 28 Nov \\
2019 \\
\hline Kata Kunci: \\
Manajemen, Mutu, \\
Pendidikan. \\
\hline
\end{tabular}

Keywords:

keyword one, keyword two, keyword three.

\begin{abstract}
ABSTRAK
Pendidikan adalah faktor yang sangat penting bagi kemajuan Bangsa dan Negara. Maka tidaklah heran jikalau manajemen mutu pendidikan adalah unsur penting yang diperhatikan oleh pemerintah untuk menghasilkan kualitas pendidikan yang baik dan unggul. Oleh sebab itu, sangat penting jikalau institusi pendidikan memperhatikan manajemen mutu melalui standart penjaminnan mutu (SPMI). Berdasarkan hal di atas, maka penelitian ini dilakukan untuk mengulas sistem SPMI yang dilakukan di STT Ebenhaezer. Dengan tujuan menghasilkan standart mutu pendidikan yang baik dan unggul seperti yang diharapkan. Maka ada beberpa hal yang dilakukan untuk mencapai hal yang dimaksud. Membangun komunikasi yang baik di semua lini kerja di STTE, secara bertahap meningkatkan alokasi anggaran ideal untuk penjaminan mutu sesuai ketentuan Kemendiknas Dikti tahun 2009, membuat panduan kriteria keberhasilan SPMI, meningkatkan kinerja staf pengelola LP2M dan penjaminan mutu di lingkungan STTE melalui penghargaan dan sanksi, mendorong terbangunnya budaya mutu yang konsisten dan berkelanjutan.
\end{abstract}

\begin{abstract}
The second abstract is written in English. Abstract length maximum 250 words. At least the abstract should include the background of the study, research methods, research results and recommendations. The abstract should include two to five keywords, and the format of writing follows the template.
\end{abstract}

\section{Pendahuluan}

Kualitas pendidikan adalah sebuah faktor kunci memperbaiki kualitas bisnis, dan karena itu memperkuat keunggulan kompetitif. Akses terhadap pendidikan dan pendidikan berkualitas harus dianggap sebagai kebutuhan dan hak yang saling bergantung dan tidak dapat dibagi. Kurangnya pendidikan (yang berkualitas) merupakan penyebab kemiskinan. Di samping itu kerusakan moral dan minimnya kecakapan hidup sudah tentu dipengaruhi proses penyelenggaraan pendidikan. Banyak negara di dunia, masih bergumul dengan masalah pendidikan, termasuk di Indonesia. Bukti nyata masalah dalam pendidikan nampak pada prosesnya, yakni 
"carut marutnya" penyelenggaran pendidikan di Indonesia, juga pada hasil (produk) pendidikan, di mana sebagian besar belum memiliki kompetensi yang diharapkan.

Demikian juga di Sekolah Tinggi Theologia Ebenhaezer (STTE). Pelaksanaan Standar Penjaminan Mutu masih perlu pembenahan. Oleh karena itu, sangat penting mengulas tentang mutu atau kualitas pendidikan dan manajemen mutu pendidikan di STTE.

\section{Metode Penelitian}

Dalam penelitian ini penulis menggunakan metode penelitian kualitatif. Penelitian kualitatif merupakan penelitian yang digunakan untuk menyelidiki, menemukan, menggambarkan, dan menjelaskan kualitas atau keistimewaan dari pengaruh social yang tidak dapat dijelaskan, diukur atau digambarkan melalui pendekatan kuantitatif. Saryono (2010).

Teknik pengumpulan data dalam penelitian ini dilakukan dengan pengamatan atau partisipasi langsung dan penelaahan dokumen.

\section{Hasil Dan Pembahasan \\ Kualitas Pendidikan}

Kata Kualitas berasal dari bahasa Latin qualitas (properti, kualitas, nilai, karakteristik, fitur, kemampuan). Dalam dunia yang sangat kompetitif dengan tuntutan konsumen yang meningkat, kualitas telah menjadi faktor kunci untuk bertahan hidup di pasar, profitabilitas dan pembangunan, tidak hanya untuk sektor dan organisasi individual, tetapi juga untuk ekonomi seluruh negara. Goetsch dan David menyebutkan definisi kualitas yang diterima secara umum menyangkut elemenelemen berikut: 1) mempertemukan harapan pelanggan (customer); 2) menyangkut aspek produk, servis, orang, proses dan lingkungan; 3) kriteria yang selalu berkembang yang berarti bahwa sebuah produk sekarang berkualitas, tetapi di lain waktu mungkin tidak lagi berkualitas.

Setiap aktivitas manusia diidentifikasi dengan kualitas produknya. Aturan yang sama berlaku untuk pendidikan. Oleh karena itu kualitas pendidikan bertanggung jawab atas kualitas "produknya" siswa/mahasiswa. Berbagai bentuk pendidikan hadir di tempat yang berbeda, pada berbagai waktu, dalam situasi dan keadaan yang berbeda, disengaja dan tidak disengaja, teratur dan tidak terorganisir, dengan atau tanpa program. Salah satu masalah utamanya adalah penyatuan standar dan kriteria evaluasi mutu.

Kualitas pendidikan adalah konsep dinamis dan multi dimensi yang mengacu tidak hanya pada model pendidikan, namun juga misi kelembagaan dan tujuannya, juga standar spesifik sistem, fasilitas, program atau acara. Teori dan praktik pedagogis telah mencoba untuk menentukan kualitas pendidikan. Di bidang pendidikan hanya mungkin untuk menentukan kualitas dengan membandingkan (mengevaluasi) hasilnya dengan tujuan yang telah ditentukan, atau dengan membandingkannya dengan standar yang telah ditetapkan sebelumnya.

Komponen kunci dari proses evaluasi adalah pendekatan metodologis dalam menerapkan metode dan prosedur pengumpulan data yang baik, dan definisi konsep utama dan hubungannya dengan konsep kualitas. Prasyarat mendasar untuk peningkatan kualitas adalah pembentukan sistem evaluasi internal dan eksternal yang 
aktif. Evaluasi internal menyiratkan peran penting pelibatan siswa sebagai peserta aktif dalam proses evaluasi kualitas dalam pendidikan.

Apa sebenarnya pendidikan itu? Istilah "Pendidikan" dalam bahasa Inggris "education" diturunkan dari dua kata Latin Educare (Educere) dan Educatum. "Educare" berarti melatih atau membentuk. Sekali lagi berarti memunculkan atau memimpin atau menarik keluar, dorongan dari dalam ke luar. Istilah "Educatum" menunjukkan tindakan mengajar. Ini menyoroti prinsip dan praktik pengajaran. Pendidikan juga dapat disebut sebagai: "a relentless process of becoming (proses tanpa henti untuk menjadi)".

Pendidikan adalah dasar pengembangan dan pemberdayaan bagi setiap bangsa. Pendidikan memainkan peran penting dalam memahami dan berpartisipasi dalam kegiatan sehari-hari di dunia sekarang ini. la membangun karakter seseorang dan memainkan peran penting dalam mentransmisikan budaya, kepercayaan dan nilai seseorang kepada orang lain di masyarakat. la juga membantu dalam menciptakan inovasi dan memenuhi kebutuhan setiap bangsa.

Maksudnya, pendidikan berperan sangat penting dalam kehidupan manusia. Maju tidaknya suatu bangsa sangat tergantung pada pendidikan bangsa tersebut. Artinya jika pendidikan suatu bangsa dapat menghasilkan manusia yang berkualitas lahir batin. Otomatis bangsa tersebut akan maju, damai dan tentram. Sebaliknya jika pendidikan suatu bangsa mengalami stagnasi maka bangsa itu akan terbelakang di segala bidang.

Dalam hal ini E. Mulyasa menyatakan bahwa: "Pendidikan memberikan kontribusi yang besar terhadap kemajuan suatu bangsa, dan merupakan wahana dalam menerjemahkan pesan-pesan konstitusi serta sarana dalam membangun watak bangsa (Nation Character Building). Masyarakat yang cerdas akan memberi nuansa kehidupan yang cerdas pula, dan secara progresif akan membentuk kemandirian. Masyarakat bangsa yang demikian merupakan investasi besar untuk berjuang ke luar dari krisis dan menghadapi yang global".

\section{Manajemen Mutu Dan Manajemen Terpadu Dalam Dunia Pendidikan}

Apa manajemen mutu atau manajemen kualitas itu? Myron Tribus mendefinisikannya sebagai: "a different way to organize the efforts of people." Tujuannya adalah untuk menyelaraskan usaha mereka sedemikian rupa sehingga orang tidak hanya mengerjakan tugas mereka dengan antusias, namun juga turut berpartisipasi dalam memperbaiki hal-hal tentang bagaimana pekerjaan dilakukan. Manajemen mutu memperkenalkan perubahan yang signifikan dalam hubungan antara mereka yang mengelola dan mereka yang benar-benar melakukan pekerjaan.

Edward Sallis menegaskan bahwa manajemen mutu terpadu adalah suatu falsafah perbaikan berkelanjutan yang dapat menyediakan lembaga pendidikan apapun dengan seperangkat alat praktis untuk memenuhi dan melampaui kebutuhan, keinginan dan harapan masa datang para pemakai. G. R. Terry, merumuskan manajemen sebagai berikut: "Management is a distinct process consisting of planning, organizing, actuating, and controlling, performed to determine and accomplish stated objectives by the use of human beings and other resources".

Manajemen merupakan salah satu kunci keberhasilan suatu organisasi dalam mencapai suatu tujuan. Perhatian ilmu manajemen terhadap peningkatan mutu suatu produk dalam dua dasa warsa ini meningkat pesat. Ada lima aktivitas yang harus dilalui 
dalam proses manajemen yakni: Perencanaan, Pengorganisasian, Penggerakan, Pengukuran, dan Pengawasan.

Sebagai lembaga yang bergerak dalam bidang industri mulia yang mengemban misi ganda yaitu profit dan sosial, maka lembaga pendidikan harus menempatkan penjaminan mutu sebagai tolok ukur untuk menilai keberhasilan atau kegagalannya. Sebab tanpa ada penjaminan mutu, lembaga pendidikan sulit untuk melihat sejauh mana berkualitas atau tidak berkualitasnya lulusan.

Dua hal terpenting yang mempengaruhi kualitas pendidikan adalah kepemimpinan dan mutu manajemen. Kepemimpinan yang efektif dan mutu manajemen, eksistensi lembaga pendidikan akan dapat terselenggara dan berjalan secara maksimal dalam menghadapi persaingan di masa yang akan datang melalui perbaikan secara terus menerus atas jasa, manusia, produk dan lingkungan.

Konsep kualitas dalam pengelolaan lembaga pendidikan seharusnya benar-benar tanggap dan konsisten terhadap kualitas, baik kualitas manajemen yang dilihat dari proses maupun kualitas kegiatan-kegiatan pendidikan dan produk pelayanan jasa pendidikan.

Di bidang pendidikan, manajemen peningkatan mutu (MPM) dapat didefinisikan sebagai sekumpulan prinsip atau teknik yang menekankan bahwa peningkatan mutu harus bertumpu pada lembaga pendidikan untuk secara terus menerus dan berkesinambungan meningkatkan kapasitas dan kemampuan organisasinya guna memenuhi tuntutan dan kebutuhan peserta didik dan masyarakat. Di dalam MPM terkandung beberapa upaya:

- Mengendalikan proses yang berlangsung di lembaga pendidikan atau sekolah baik kurikuler maupun administrasi.

- Melibatkan proses diagnosis dan proses tindakan untuk menindak lanjuti diagnosis.

- Peningkatan mutu harus ditingkatkan atas data dan fakta baik yang bersifat kualitatif maupun kuantitatif.

- Peningkatan mutu harus ditingkatkan secara terus menerus dan berkesinambungan.

- Peningkatan mutu harus memberdayakan dan melibatkan semua unsur yang ada di lembaga pendidikan.

- Peningkatan mutu memiliki tujuan yang menyatakan bahwa sekolah dapat memberikan kepuasan kepada peserta didik, orang tua dan masyarakat.

Salah satu bentuk manajemen yang berupaya untuk meningkatkan dan mempertahankan kualitas atau mutu industri tersebut adalah total quality management (TQM) yang diterjemahkan ke dalam bahasa Indonesia menjadi manajemen kendali mutu ada pula yang mengatakannya Manajemen Peningkatan Mutu.

\section{Standar Penjaminan Mutu}

Bagian ini akan mengulas standar penjaminan mutu yang dilakukan di Perguruan Tinggi. Penjaminan Mutu di Perguruan Tinggi dapat didefinisikan sebagai: "systematic management and assessment procedures adopted by higher education institutions and systems in order to monitor performance against objectives, and to ensure achievement of quality outputs and quality improvements". 
Intinya, sistem penjaminan mutu bertujuan untuk memberikan bukti yang tepat untuk mendukung klaim yang dibuat tentang kualitas sehingga memungkinkan pemangku kepentingan memiliki keyakinan tentang pengelolaan kualitas dan tingkat hasil yang dicapai. Jaminan kualitas melayani sejumlah tujuan. Selain melindungi kepentingan mahasiswa dan pengusaha serta memfasilitasi pengakuan internasional, ini merupakan elemen penting untuk tujuan akuntabilitas publik Jaminan kualitas membantu memberi pilihan bagi mahasiswa, terutama karena keragaman penawaran perguruan tinggi yang semakin beragam. Ini juga dapat berkontribusi pada proses pengajaran dan administrasi yang lebih baik dan membantu penyebaran praktik yang baik, yang mengarah pada peningkatan sistem secara keseluruhan.

Di Indonesia, pemerintah telah menerbitkan UU No. 12 Tahun 2012 Tentang Pendidikan Tinggi, Pasal 7 ayat (3) huruf c, yang mengatur Tugas dan wewenang Menteri atas penyelenggaraan Pendidikan Tinggi meliputi: (c) peningkatan penjaminan mutu, relevansi, keterjangkauan, pemerataan yang berkeadilan, dan akses Pendidikan Tinggi secara berkelanjutan.

Selanjutnya dalam Sistem Penjaminan Mutu Pendidikan Tinggi (SPM Dikti) ada hal-hal yang didefinisikan yakni Mutu pendidikan tinggi, Sistem Penjaminan Mutu Pendidikan Tinggi, Sistem Penjaminan Mutu Internal, Sistem Penjaminan Mutu Eksternal, dan Pangkalan Data Pendidikan Tinggi:

Mutu pendidikan tinggi adalah tingkat kesesuaian antara penyelenggaraan pendidikan tinggi dengan Standar Pendidikan Tinggi yang terdiri atas Standar Nasional Pendidikan Tinggi dan Standar Pendidikan Tinggi yang Ditetapkan oleh Perguruan Tinggi.

Sistem Penjaminan Mutu Pendidikan Tinggi (SPM Dikti) adalah kegiatan sistemik untuk meningkatkan mutu pendidikan tinggi secara berencana dan berkelanjutan.

Sistem Penjaminan Mutu Internal (SPMI) adalah kegiatan sistemik penjaminan mutu pendidikan tinggi oleh setiap perguruan tinggi secara otonom untuk mengendalikan dan meningkatkan penyelenggaraan pendidikan tinggi secara berencana dan berkelanjutan.

Sistem Penjaminan Mutu Eksternal (SPME) adalah kegiatan penilaian melalui akreditasi untuk menentukan kelayakan dan tingkat pencapaian mutu program studi dan perguruan tinggi.

Pangkalan Data Pendidikan Tinggi (PD Dikti) adalah kumpulan data penyelenggaraan pendidikan tinggi seluruh perguruan tinggi yang terintegrasi secara nasional. Kelima hal tersebut saling terpadu dalam pemahaman dan implementasinya, sebagai instrument penjaminan mutu yang disediakan pemerintah Republik Indonesia.

SPMI direncanakan, dilaksanakan, dikendalikan, dan dikembangkan oleh perguruan tinggi. SPME direncanakan, dilaksanakan, dikendalikan, dan dikembangkan oleh BAN PT dan/atau LAM melalui akreditasi sesuai dengan kewenangan masingmasing. Luaran penerapan SPMI oleh Perguruan Tinggi digunakan oleh BANPT atau LAM untuk penetapan status dan peringkat terakreditasi Perguruan Tinggi atau progam studi. SPMI dan SPME mengacu pada Standar Pendidikan Tinggi.

Good University Governance (GUG) merupakan prasyarat dalam melaksanakan kewenangan otonom pada Pendidikan Tinggi, terutama pada aspek akuntabilitas dan transparansi yang dituangkan dalam bentuk kebijakan SPMI. Kebijakan mutu SPMI bertujuan untuk memberikan arah dan landasan pengembangan kebijakan mutu 
Sasaran adalah untuk meningkatkan mutu, efisiensi dan efektivitas kinerja di seluruh unit kerja.

Sistem Penjaminan Mutu Perguruan Tinggi (SPM Dikti) mengintegrasikan antara penjaminan mutu yang diselenggarakan oleh masing-masing Perguruan Tinggi yang disebut penjaminan mutu internal. Dengan penjaminan mutu eksternal yang disebut akreditasi, berdasarkan satu basis data dan informasi yang dikelola dalam pangkalan data perguruan tinggi. Penerapan Sistem Penjaminan Mutu Internal Perguruan Tinggi (SPMI) yang dilaksanakan oleh Perguruan Tinggi dapat dikembangkan secara otonom atau mandiri melalui 5 (lima) langkah utama yang disingkat PPEPP, yaitu Penetapan, Pelaksanaan, Evaluasi, Pengendalian, dan Peningkatan Standar Dikti. Secara garis besarnya apabila setiap Perguruan Tinggi dapat melaksanakan kelima langkah tersebut secara konsisten berdasarkan apa yang telah digariskan dalam UU Dikti, maka Perguruan Tinggi tersebut pastilah bermutu.

\section{Sistim Penjaminan Mutu Internal}

Dirjen Pendidikan Tinggi Kementerian Pendidikan Nasional menyatakan bahwa: Sistem Penjaminan Mutu Internal (SPMI) di suatu perguruan tinggi merupakan kegiatan mandiri dari perguruan tinggi yang bersangkutan, sehingga proses tersebut dirancang, dijalankan, dan dikendalikan sendiri oleh perguruan tinggi yang bersangkutan tanpa campur tangan dari Pemerintah, dalam hal ini Direktorat Jenderal Pendidikan Tinggi, Depdiknas. Dengan demikian, pedoman SPMI ini tidak bertujuan 'mendikte' perguruan tinggi agar menjalankan proses penjaminan mutu seperti diuraikan di dalamnya, melainkan pedoman ini bertujuan memberikan inspirasi tentang berbagai aspek yang pada umumnya terkandung dalam SPMI di suatu perguruan tinggi. Kebijakan ini diambil karena disadari bahwa setiap perguruan tinggi memiliki spesifikasi yang berlainan, antara lain dalam hal sejarah, visi dan misi, budaya organisasi, ukuran organisasi (jumlah program studi, jumlah dosen, jumlah mahasiswa), struktur organisasi, sumber daya, dan pola kepemimpinan.

Konsep SPMI adalah suatu perguruan tinggi dinyatakan bermutu apabila:

a. Perguruan tinggi mampu menetapkan dan mewujudkan visinya;

b. Perguruan tinggi mampu menjabarkan visinya ke dalam sejumlah standar dan standar turunan;

c. Perguruan tinggi mampu menerapkan, mengendalikan, dan mengembangkan sejumlah standar dan standar turunan dalam butir b untuk memenuhi kebutuhan stakeholders.

Mekanisme atau siklus SPMI sebagaimana yang tertulis pada pasal 52 ayat 2 Undang-undang No. 12 tahun 2012 tentang Pendidikan Tinggi mencakup tahap-tahap Penetapan, Pelaksanaan, Evaluasi, Pengendalian dan Peningkatan. Dengan acuan siklus tersebut maka suatu perguruan tinggi harus membuat sejumlah dokumen SPMI yang meliputi dokumen kebijakan, dokumen manual, dokumen standar dan formulirformulir/boring (proforma).

\section{Dokumen Kebijakan}

Kebijakan SPMI Perguruan Tinggi adalah dokumen berisi uraian secara garis besar tentang bagaimana suatu Perguruan Tinggi memahami, merancang, dan 
mengimplementasikan SPMI Perguruan Tinggi dalam penyelenggaraan pendidikan tinggi, sehingga terwujud budaya mutu pada Perguruan Tinggi tersebut. Di dalam dokumen ini terdapat uraian mengenai: latar belakang atau alasan, tujuan, strategi, prinsip dan arah Perguruan Tinggi untuk menjamin dan meningkatkan mutu dalam setiap kegiatannya.

Dokumen Kebijakan SPMI Perguruan Tinggi bermanfaat untuk:

- menjelaskan kepada para pemangku kepentingan Perguruan Tinggi tentang SPMI di Perguruan Tinggi yang bersangkutan secara ringkas, padat, dan utuh;

- menjadi dasar atau 'payung' bagi seluruh Standar, Manual, dan Formulir SPMI di Perguruan Tinggi;

- membuktikan bahwa SPMI Perguruan Tinggi yang bersangkutan terdokumentasikan.

Dokumen Kebijakan SPMI Perguruan Tinggi atau Kebijakan Mutu sebaiknya terdiri atas paling banyak 20 (dua puluh) halaman.

\section{Dokumen Manual}

Manual SPMI Perguruan Tinggi adalah dokumen berisi petunjuk mengenai cara, langkah, atau prosedur tentang penetapan, pelaksanaan, evaluasi pelaksanaan, pengendalian pelaksanaan, dan peningkatan setiap Standar Dikti oleh para pihak pada semua aras di dalam Perguruan Tinggi.

Dokumen Manual SPMI Perguruan Tinggi bermanfaat sebagai:

- Pemandu bagi para pejabat struktural dan/atau unit SPMI di Perguruan Tinggi, dosen, serta tenaga kependidikan dalam mengimplementasikan SPMI Perguruan Tinggi sesuai dengan tugas dan wewenang masing-masing sehingga terwujud budaya mutu;

- Petunjuk tentang bagaimana Standar Dikti dapat dipenuhi dan ditingkatkan secara berkelanjutan;

- Bukti tertulis bahwa SPMI di Perguruan Tinggi yang bersangkutan telah siap diimplementasikan.

Manual SPMI Perguruan Tinggi sebaiknya berisi petunjuk praktis tentang cara menetapkan (merancang dan merumuskan), melaksanakan, mengevaluasi pelaksanaan, mengendalikan pelaksanaan, serta meningkatkan secara berkelanjutan Standar SPMI Perguruan Tinggi. Manual juga berisi bagaimana semua pejabat struktural atau unit khusus SPMI Perguruan Tinggi mengimplementasikan SPMI Perguruan Tinggi secara sistemik dalam satu siklus utuh pada semua aras dalam Perguruan Tinggi.

\section{Dokumen Standar}

Standar SPMI Perguruan Tinggi adalah dokumen berisi berbagai kriteria, ukuran, patokan, atau spesifikasi yang disebut Standar Pendidikan Tinggi atau Standar Dikti dari setiap aspek pendidikan tinggi di suatu Perguruan Tinggi untuk mewujudkan visi dan misinya.

Di dalam SPMI Perguruan Tinggi, standar adalah pernyataan tertulis yang berisi hal berikut ini: 
- Spesifikasi atau rincian tentang sesuatu hal khusus, yang memperlihatkan sebuah tujuan, cita-cita, keinginan, kriteria, ukuran, patokan, pedoman;

- Perintah agar melakukan sesuatu untuk mencapai atau memenuhi spesifikasi dalam angka 1 di atas;

- Kualifikasi mutu yang akan dicapai oleh Perguruan Tinggi.

Dengan demikian isi sebuah standar akan dapat berupa sesuatu yang berupa input, proses, prosedur, atau hasil akhir (produk).

Dokumen Standar SPMI Perguruan Tinggi berfungsi sebagai:

- Alat ukur dalam mewujudkan visi, misi, dan tujuan Perguruan Tinggi;

- Indikator untuk menunjukkan tingkat (level) mutu Perguruan Tinggi;

- Tolok ukur capaian oleh semua pihak di Perguruan Tinggi, sehingga menjadi faktor pendorong untuk bekerja dengan (atau bahkan melebihi) standar;

- Bukti otentik kepatuhan Perguruan Tinggi terhadap peraturan perundangundangan tentang Standar Dikti; dan

- Bukti kepada masyarakat bahwa Perguruan Tinggi tersebut telah secara sungguh-sungguh menyelenggarakan pendidikan tinggi berdasarkan standar.

Standar SPMI Perguruan Tinggi harus memenuhi dan melampaui Standar Nasional Pendidikan Tinggi (SN Dikti) sebagaimana diatur dalam peraturan perundangundangan.

\section{Dokumen Formulir (Proforma)}

Formulir atau Borang atau Proforma SPMI Perguruan Tinggi adalah dokumen yang berfungsi untuk mencatat atau merekam hal atau informasi tentang pencapaian Standar SPMI Perguruan Tinggi.

Dokumen Formulir atau Borang atau Proforma SPMI Perguruan Tinggi berfungsi sebagai:

- Alat untuk mengukur pencapaian atau pemenuhan atau pelampauan Standar SPMI Perguruan Tinggi;

- Alat untuk memantau, mengevaluasi, mengendalikan, dan mengoreksi implementasi SPMI Perguruan Tinggi;

- Bukti otentik untuk mencatat atau merekam implementasi SPMI Perguruan Tinggi secara periodik.

Terdapat berbagai macam Formulir atau Borang atau Proforma SPMI Perguruan Tinggi dengan peruntukan yang berbeda-beda sesuai dengan Standar SPMI Perguruan Tinggi yang diimplementasikan. Setiap Standar SPMI Perguruan Tinggi pasti membutuhkan paling sedikit satu macam formulir. Setiap perguruan tinggu membutuhkan dokumen formulir untuk mencatat informasi tentang pencapaian standar Perguruan Tinggi tersebut.

\section{Penerapan SPMI Di Sekolah Tinggi Theologia Ebenhaezer}

Penerapan Sistem Penjaminan Mutu Internal (SPMI) di STT Ebenhaezer Tanjung Enim merupakan kegiatan mandiri yang dirancang, dijalankan, dan dikendalikan oleh Pusat Penjaminan Mutu (PPM). SPMI yang diterapkan merupakan evaluasi diri terhadap proses perencanaan, pemenuhan, pengendalian, dan pengembangan standar mutu secara konsisten dan berkelanjutan. Penerapan SPMI bagi pemangku 
kepentingan (stakeholders) internal dilakukan paralel dengan Sistem Penjaminan Mutu Eksternal (SPME) dengan sistem akreditasi oleh lembaga independen yang berwenang dan kredibel.

Untuk menghasilkan sebuah proses akademik yang sesuai dengan tuntutan SPMI dan SPME itu, maka diperlukan standar mutu yang dapat dipertanggungjawabkan kepada stakeholder agar penetapan baku mutu (benchmark) STTE sesuai dengan tuntutan masyarakat luas sebagai bentuk komitmen, tanggungjawab moral, dan transparansi lembaga perguruan tinggi ini terhadap publik.

Di STTE, berdasarkan pengamatan penulis, implementasi SPMI pada semua aras belum terimplementasikan secara optimal. Hal ini dapat dilihat pada lima siklus yakni penetapan standar, pelaksanaan standar, evaluasi standar, pengendalian dan peningkatan.

\section{Pada Penetapan Standar}

STTE belum konsisten melakukan analisis SWOT baik pada aras Institusi maupun pada unit kerja lainnya di lingkungan sekolah tinggi. Juga belum melakukan pelacakan terhadap lulusan (alumni) dan pengguna lulusan.

\section{Pada Pelaksanaan Standar}

STTE belum melaksanakan semua standar Dikti yang tertuang dalam pelaksanaan standar Dikti. Misalnya pada standar pembelajaran; tidak semua dosen menyusun Rencana Pembelajaran Semester (RPS) mata kuliah yang diajarkan. Sehingga materi yang dijarkan dosen kepada mahasiswa tidak tersusun secara sistimatis.

Di samping standar pembelajaran, santar lain yang belum dilaksanakan adalah standar rekrutmen dan seleksi dosen. Kenyataan yang terjadi, STTE menerima dosen bukan berdasarkan kriteria yang sudah ditentukan sesuai kualitas akademik, melainkan menerima dosen, di mana status calon dosen dimaksud adalah tenaga ikatan dinas dan tidak memenuhi kualifikasi akademik. Awalnya tenaga ikatan dinas tersebut hanya ditempatkan sebagai tenaga membantu administrasi.

\section{Pada Evaluasi Standar}

Implementasi tahap evaluasi di STTE yang merupakan tanggung jawab pejabat struktural, mulai dari Ketua, para pembantu ketua dan unit kerja, tidak dilakukan secara konsisten berdasarkan aturan-aturan yang ada pada standar Dikti, sehingga keluaran (output) dan hasil (outcomes) belum terpenuhi sesuai harapan. Pada gilirannya, mutu penyelenggaraan perguruan tinggi belum terjamin. Sebagai contoh, belum tersedia buku-buku yang menjadi menjadi pedoman evaluasi. Kondisi inilah yang berdampak pada evaluasi sesuai standar Dikti.

\section{Pada Pengendalian Standar}

Pengendalian merupakan tindak lanjut atas hasil yang diperoleh dari kegiatan evaluasi. Karena evaluasi di STTE ditemukan kekeliruan, ketidaktepatan yang menyebabkan kegagalan pencapaian isi standar, maka berimbas pada tindakan pengendalian. 


\section{Pada Peningkatan Standar}

Tahap akhir standar Dikti adalah kegiatan meningkatkan isi atau luas lingkup standar Dikti dalam SPMI. Di STTE, peningkatan standar Dikti masih sulit dilakukan. Kegiatan-kegiatan dimaksud misalnya, penelitian, diskusi dengan para pemangku kepentingan, studi pelacakan lulusan, analisis SWOT, upah (allowance) dan remunerasi, studi lanjut dosen dan pendanaan. Hal ini dikarenakan tahapan-tahapan sebelumnya dari siklus ini belum baik dilakukan.

\section{Strategi Demi Perbaikan Mutu di STTE}

Ada beberapa strategi yang harus diupayakan demi perbaikan mutu penyelenggaraan pendidikan di STTE, yaitu:

- Meningkatkan pemahaman dan komitmen pimpinan STTE, pengelola penjaminan mutu, LP2M dan seluruh sivitas akademika untuk memahami, merancang dan melaksanakan SPMI melalui kegiatan workshop, lokakarya, serta diseminasi dan sosialisasi.

- Membangun komunikasi yang baik di semua lini kerja di STTE.

- Secara bertahap meningkatkan alokasi anggaran ideal untuk penjaminan mutu sesuai ketentuan Kemendiknas Dikti tahun 2009.

- Membuat panduan kriteria keberhasilan SPMI.

- Meningkatkan kinerja staf pengelola LP2M dan penjaminan mutu di lingkungan STTE melalui penghargaan dan sanksi.

- Mendorong terbangunnya budaya mutu yang konsisten dan berkelanjutan.

\section{Kesimpulan}

Mutu suatu kegiatan pendidikan ditentukan sejak dimulai, pada proses dan dan produk atau hasil kegiatan pendidikan tersebut. Produk yang baik, yang datang dari manajemen yang baik pada gilirannya akan memberikan kontribusi positif baik berupa image yang baik, maupun partisipasi pada dunia kerja.

Karena itu perlu ditetapkan suatu standar mutu pendidikan yang berlaku global dan nasional, sehingga lembaga-lembaga penyelenggara pendidikan dapat menyelenggarakan pendidikan, dan mengadakan evaluasi terus menerus dalam penyelenggaraan pendidikan yang dilakukan.

STTE sedang melaksanakan standar pelaksanaan pendidikan sesuai anjuran Dikti. Akan tetapi penerapan SPMI masih perlu upaya serius, dimulai dari menyiapkan dokumen-dokumen dari setiap siklus (PPEPP) yang ditetapkan Dikti. 


\section{Kepustakaan}

Direktorat Jenderal Pendidikan Tinggi, Kementerian Pendidikan Nasional, Hairiyah, $2010 \quad$ Sistem Penjaminan Mutu Perguruan Tinggi. Jakarta: Dirjen Dikti

2015 “Konsep Manajemen Mutu Terpadu dalam Pendidikan”, Jurnal Literasi, Volume VI, No. 1

Harman, Grant 2000 "Introduction", Quality Assurance in Higher Education, Proceedings of the International Conference on Quality Assurance in Higher Education: Standards, Mechanisms and Mutual Recognition. Bangkok, Thailand.

Karmakar, Anupam and Bisdisha Sarkar Datta,

2012 Principles And Practice Of Management and Business Communication, India: Dorling Kondersley Pvt. Ltd.

Maliah,

Tt Kebijakan Sistem Penjaminan Mutu Internal di Perguruan Tinggi. Universitas PGRI Palembang, Ketua Gugus Penjamin Mutu.

Muhtaram, Aceng M.,

Tt Strategi penerapan Manajemen Mutu Dalam Sistem PendidikanNasional.,3.http://file.upi.edu/Direktori/FIP/JUR._ADMI NISTRASI_PENDIDIKAN/195706161986011ACENG_MUHTARAM_MIRFANI/Penerapan-Manajemen-

Mustafa, Delly, Mutu_by-AM.Mirfani.pdf.

Tt Penerapan Sistem Penjaminan Mutu Internal di Perguruan Tinggi (UPRI) Makassar. Fakultas Ilmu Sosial dan Ilmu Politik (FiSiPol) UPRI Makassar.

Reddy, V., Narayan Karan,

1979 Man Education and Values, New Delhi: B.R. Publication.

Suryoatmono, Bambang dkk.,

2016 Bahan Pelatihan Sistim Penjaminan Mutu Internal Perguruan Tinggi. Kementerian Riset, Teknologi dan Pendidikan Tinggi, Direktorat Jenderal Pembelajaran dan Kemahasiswaan Direktorat Penjaminan Mutu.

Suto, Prabowo, 2012 “Total Quality Management (TQM) dalam Pendidikan”, Jurnal Sosial Humaniora, Vol 5 No.1.

Syukron, Buyung, 2016

"Implementasi Manajemen Mutu Terpadu Studi Transformatif pada Perguruan Tinggi”, Jurnal Penelitian, Vol. 10, No. 2.

Tribus, Myron, Tt Quality Management in Education, Exergy, Inc.

Hayward, CA

http://www.qla.com.au/pathtoitems/QMGT_INE.PDF. 
Vlašić, Suzana, Smiljana Vale, Danijela Križman Puhar,

$\mathrm{Tt}$

Quality Management in Education, Interdisciplinary Management Research.

Yusuf, Musfirotun

2009

"Membangun Manajemen Mutu Pendidikan Menghadapi Tantangan Global”, Forum Tarbiyah Vol. 7, No. 1.

Education - Meaning, Origin, History and Philosophy of Education

http://shodhganga.inflibnet.ac.in/bitstream/10603/8

116/11/11_chapter\%202.pdf 